\title{
Mentoring dan Sosialisasi Teknologi Pengemasan Olahan Nanas di Desa Babadan Kecamatan Ngancar Kabupaten Kediri
}

\author{
Nunuk Helilusiatiningsih ${ }^{1}$, Edy Soenyoto $^{2}$, Imam Habibi $^{3}$ \\ Ertika Fitri Lisnanti ${ }^{4}$ \\ $1,2,3,4$ Universitas Islam Kadiri \\ email : nunukhelilusi@gmail.com ${ }^{1}$
}

\begin{abstract}
Pineapples, which are widely grown in Ngancar District, Kediri Regency, are the region's superior product. In Babadan Village, post-harvest processing and pineapple fruit packing technology are still uncommon. This program was designed to stimulate people's interest in and ability to do business with high-quality fresh and processed pineapples that are properly packaged for safety and appeal. Counseling on post-harvest handling and packaging technology for pineapple processing, as well as help to PKK groups, are carried out as part of the service activities. The session took place at the Babadan Village Hall from 10:00 to 12:00 on the 20th and 21st of August, 2021, and was attended by 20 people from Babadan Village. Members of the agricultural cooperative Langgeng Mulyo's management and the head village accompanied and supported the training participants in their efforts to establish an agribusiness. A cooperation between the farmers and academics is carried out with the business incubator study center of the Faculty of Agriculture, Kadiri Islamic University, Kediri.
\end{abstract}

Keywords: processed pineapple, mentoring, socialization, packaging technology.

\begin{abstract}
Abstrak
Tanaman nanas yang banyak ditanam di kecamatan Ngancar, kabupaten Kediri merupakan produk unggulan petani. Penanganan pasca panen dan teknologi pengemasan buah nanas masih jarang dilakukan oleh petani nanas di desa Babadan. Kegiatan ini bertujuan untuk mendorong minat dan kemampuan dalam melakukan usaha bisnis nanas segar dan olahan yang bermutu yang dikemas baik agar aman dan menarik. Kegiatan pengabdian dilakukan dengan cara penyuluhan tentang penanganan pasca panen dan teknologi pengemasan olahan nanas, dan pendampingan kepada kelompok PKK. Pelatihan dihadiri 20 orang dari desa Babadan, selama 2 hari mulai tanggal 20 sampai 21 Agustus 2021 berlokasi di balai desa Babadan mulai pukul 10.00 sampai 12.00. Peserta pelatihan didampingi dan didukung oleh anggota pengurus koperasi pertanian Langgeng Mulyo dan bapak kepala desa Babadan untuk mewujudkan usaha agribisnis. Hasil kegiatan menunjukan adanya respon positif dari peserta untuk mengembangkan menjadi UKM pengolahan nanas dengan dukungan akademisi, pemerintah, pihak swasta serta bank yang siap memberi kredit usaha bisnis nanas. Kerjasama dengan akademisi dilakukan dengan pusat kajian inkubator bisnis Fakultas Pertanian Universitas Islam Kadiri, Kediri.
\end{abstract}

Kata Kunci: olahan nanas, mentoring, sosialisasi, teknologi pengemasan.

\begin{tabular}{|c|c|c|c|}
\hline Artikel diterima & 29 Agustus 2021 & direvisi : 18 September 2021 & disetujui : 25 September 2021 \\
\hline (c) (i) (? & $\begin{array}{l}\text { Ciptaan dise } \\
\text { BerbagiSerup }\end{array}$ & $\begin{array}{l}\text { askan di bawah Lisensi } \\
\text { Internasional. }\end{array}$ & Creative Commons Atribusi- \\
\hline
\end{tabular}




\section{Pendahuluan}

Di desa Babadan kecamatan Ngancar banyak ditanam buah nanas. Buah nanas merupakan produk unggulan di lokasi tersebut dan dijual dalam bentuk segar ke berbagai lokasi sesuai permintaan pasar. Setelah dipanen buah nanas beresiko mengalami kerusakan akibat penanganannya kurang tepat sehingga menimbulkan busuk dan harganya murah. Teknologi pengolahan dan pengemasan buah segar dan olahan belum banyak dikenal dan dipahami oleh petani setempat. Oleh karena itu pemberian wawasan ilmu sangat diperlukan untuk meningkatkan mutu hasil panen teknologi pasca panen buah nanas penting untuk disosialisasikan agar dapat memperkecil kerusakan hasil. Menurut Astuti et al. (2019) masih banyak masyarakat yang belum mengerti bagaimana mengolah produk buah lokal seperti buah nanas agar lebih awet tidak cepat busuk dan menarik bagi pembeli serta memiliki nilai jual tinggi.

Teknologi pengemasan pangan berkembang sejalan dengan waktu meliputi pengemasan tradisional hingga modern yang merupakan faktor penting terhadap usaha bisnis. Pengemasan berfungsi untuk melindungi produk, menampilkan identitas, memberi informasi, dan meningkatkan performa produk. Hal tersebut dapat meningkatkan daya pikat pembeli, meningkatkan keuntungan serta daya saing produk (Nurcholis et al., 2012). Faktor yang dapat merusak pangan dan kemasan yaitu alam (sinar matahari, debu, air terutama air laut, tekanan udara, RH, oksigen), tekanan mekanis, kontaminasi mikroba, serta adanya reaksi kimia dari produknya (Anonim, 2007). Teknik pengemasan dan labeling yang bagus dan menarik sangat dibutuhkan dalam proses pemasaran produk makanan atau minuman.

Menurut Kotler \& Keller (2009) kegiatan pengemasan meliputi proses merancang serta memproduksi wadah atau bungkus, untuk mengawetkan serta mempertahankan kualitas produk agar terhin- dar dari kerusakan, pencemaran serta tekanan fisik seperti gesekan dan benturan. Simamora (2007) menjelaskan bahwa kemasan mempunyai fungsi protektif dan promosional. Fungsi protektif adalah upaya untuk menghindar dari kerusakan produk, baik karena iklim maupun distribusi. Menurut Julianti \& Nurminah (2006), kemasan dapat diklasifikasikan sebagai berikut: kemasan berdasarkan frekwensi pemakaian, kemasan berdasarkan struktur sistem kemas, kemasan berdasarkan sifat kekakuan bahan kemasan, kemasan berdasar sifat perlindungan terhadap lingkungan.

Sementara itu label merupakan identitas suatu produk agar konsumen dapat membedakan antara produk satu dengan yang lain. Informasi yang sebaiknya dicantumkan pada label adalah nama produk, pembuat produk, alamat pembuat produk, bahan yang dipakai untuk menghasilkan produk, kompoisi gizinya, waktu kadaluarsa, serta izin dari depkes / instansi terkait (Santi, 2015).

Tujuan kegiatan ini adalah pembinaan dan sosialisasi tentang pentingnya ilmu teknologi dan pengemasan olahan nanas. Adapun sasaran kegiatan adalah nanas dan kelompok PKK Mandiri Desa Babadan. Target yang telah dicapai meliputi target jangka pendek yakni petani memahami dan merubah secara perlahan pola pikir dalam penanganan pasca panen buah nanas serta cara pengemasan olahan nanas. Sedangkan target jangka panjang adalah terjalinnya koordinasi serta kemitraan dengan pemangku kepentingan terkait yaitu pihak akademisi, swasta dan pemerintah yang bisa memotivasi dan menumbuhkan rasa percaya diri petani dan kelompok sasaran dalam melakukan kegiatan agribisnis yang baik. Hal tersebut diharapkan bisa menaikkan pendapatan petani yang berkelanjutan.

\section{Metode Pelaksanaan}

Kegiatan pengabdian dilaksanakan di desa Babadan kecamatan Ngancar kabupaten Kediri pada tanggal 20 sampai 
21 Agustus 2021 di balai desa tepatnya beralamatkan Jl. Merdeka No. 1 desa Babadan kecamatan Ngancar kabupaten Kediri. Kegiatan berupa penyuluhan dan pelatihan kepada 20 orang kelompok tani PKK Mandiri. Kegiatan dimulai Pkl 10.00-12.00 WIB.

Pelaksanaan kegiatan pengabdian kepada masyarakat diawali dengan sambutan bapak kepala desa Babadan yaitu Bpk. Arif Priyo Wioko dilanjutkan perkenalan perwakilan lembaga. Kemudian penyampaian materi oleh narasumber tentang teknologi pengemasan bahan pangan. Pelatihan ini memberi informasi tentang jenis bahan kemasan, cara pengemasan, dan labelling untuk mendukung usaha agribisnis agar dapat dijual dengan harga yang lebih tinggi dengan kemasan yang lebih baik. Kemudian dilanjutkan dengan diskusi.

\section{Hasil Dan Pembahasan}

Poin-poin yang disampaikan pemateri adalah membahas permasalahan petani buah nanas saat ini. Menyampaikan pengertian tentang teknologi Pasca Panen dan kemasan produk yang diolah. Pengembangan UMKM masa yang akan dating, peluang usaha bisnis dan olahan. Pembukaan acara mentoring dan sosialisasi oleh kepala desa dapat ditunjukkan Gambar 1.

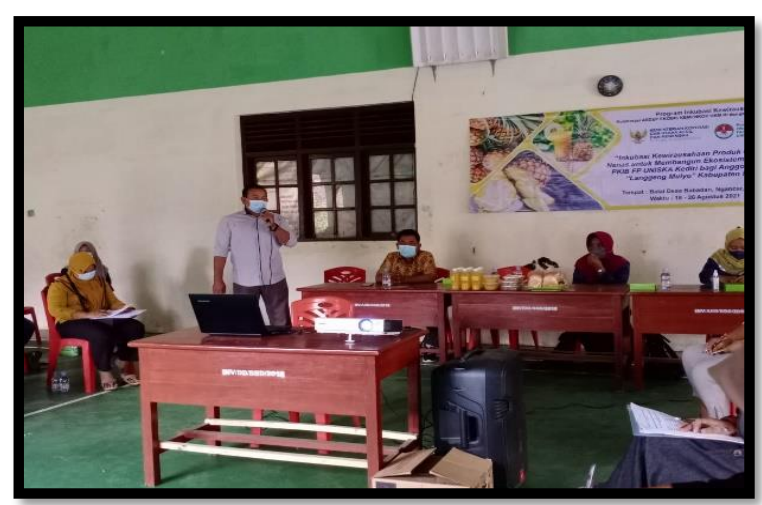

Gambar 1. Pelatihan dibuka oleh Kepala Desa Babadan

Narasumber yang diwakili dari tim pusat kajian inkubator bisnis Fakultas Pertanian UNISKA yaitu Ibu Dr. Nunuk
Helilusiatiningsih, SP., MP, yang merupakan dosen fakultas pertanian menyampaikan materi teknologi pengemasan produk, pengertian dan manfaat bahan pengemas, karakteristik kemasan, jenis - jenis bahan kamasan, dan labeling. Pemateri memberi kesempatan untuk diskusi secara langsung kepada semua peserta secara bergantian tentang masalah yang kurang paham dan diatur moderator dengan durasi waktu pelatihan 2 jam seperti Gambar 2 .

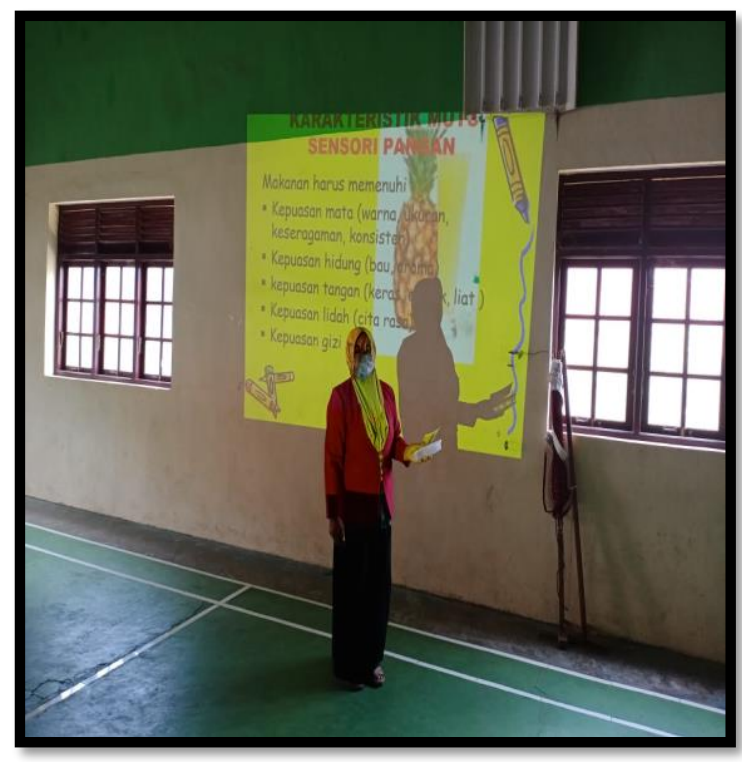

Gambar 2. Narasumber

Pada Gambar 3. merupakan jenis kemasan yang dipilih untuk produk olahan sari nanas, selai nanas, dodol nanas yang menggunakan bahan plastik sedangkan labeling menggunakan kertas yang sudah dicetak menarik. Label menunjukkan identitas produk yang dikemas dengan menggambarkan dan memuat yaitu merk perdagangan, nama produk yang dikemas, komposisi bahan, nilai gizi, berat produk, nilai gizi, produsen bisa ditambah alamatnya, ijin produksi dan waktu kadaluwarsa. Pengemas harus dalam kondisi steril sebelum produk dimasukkan dalam kemasan. Menurut Furqon et al. (2016) menjelaskan bahan kemasan dari plastik dan lama penyimpanan berpengaruh nyata pada kandungan air dan protein nugget gembus, yang tergolong plastik PP 
(polipropilen) lebih baik daripada $\mathrm{PE}$ (polietilen) bisa disimpan selama 20 hari.

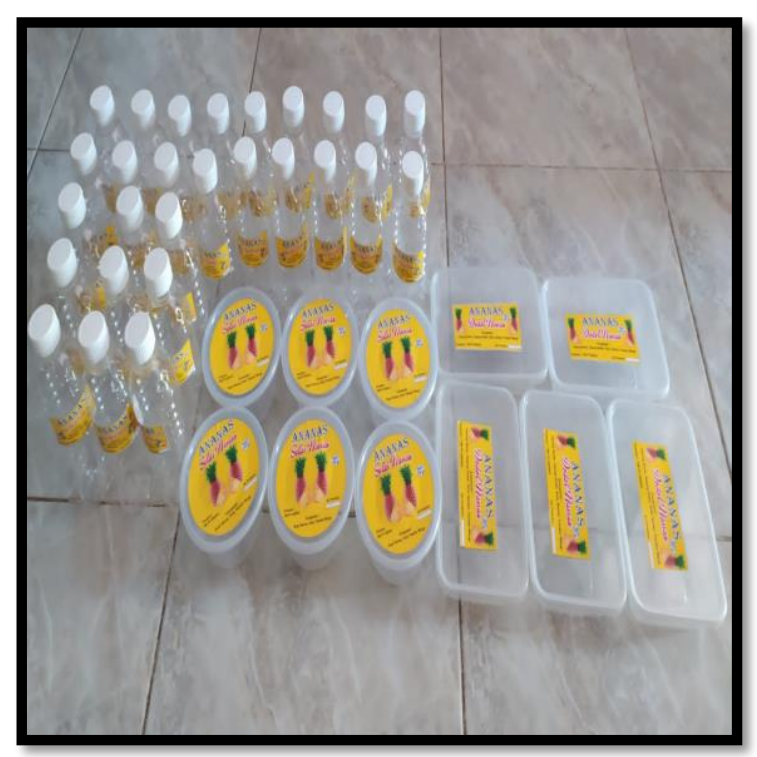

Gambar 3. Jenis bahan Kemasan Produk Olahan Nanas Dan Labeling

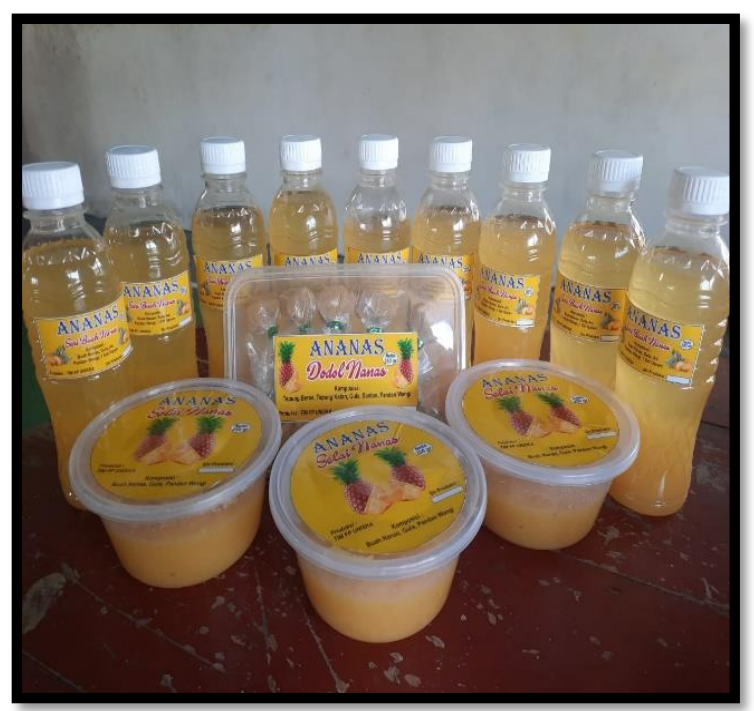

Gambar 4. Hasil olahan nanas

Hasil olahan nanas yang sudah dilakukan pengolahan bisa dimasukkan dalam wadah yang sudah disteril dan diberi label yang menarik dan cerah seperti Gambar 4. Hal ini didukung hasil Riset Menjelaskan desain yang dibutuhkan responden yang memiliki warna yang cerah, ada gambar produk serta mencetak label pada wadah yang digunakan (Elisabeth, 2017). Pendapat (Ksenia, 2013), menyatakan pengemas eye- catching sangat diminati konsumen sehingga ada rasa ingin membeli.

Hasil kegiatan pelatihan pengolahan nanas dan pengemasan akan dilanjutkan dengan materi selanjutnya tentang manajemen keuangan dalam bisnis serta strategi pemasaran oleh tim pemateri lain yang mendukung kegiatan bisnis berkelanjutan dan saling melengkapi materi yang dibutuhkan pelaku bisnis pertanian. Hal ini sesuai riset Susetyarsi (2012) bahwa konsumen memutuskan membeli produk tergantung 3 hal yaitu bahan kemasan, bentuk kemasannya dan labeling yang lengkap. Pada gambar 5. Foto bersama setelah selesai acara ditutup oleh ketua tim. Diskusi tanya jawab dipimpin moderator dan berjalan dengan baik dan nyaman serta tetap menjaga protokol kesehatan.

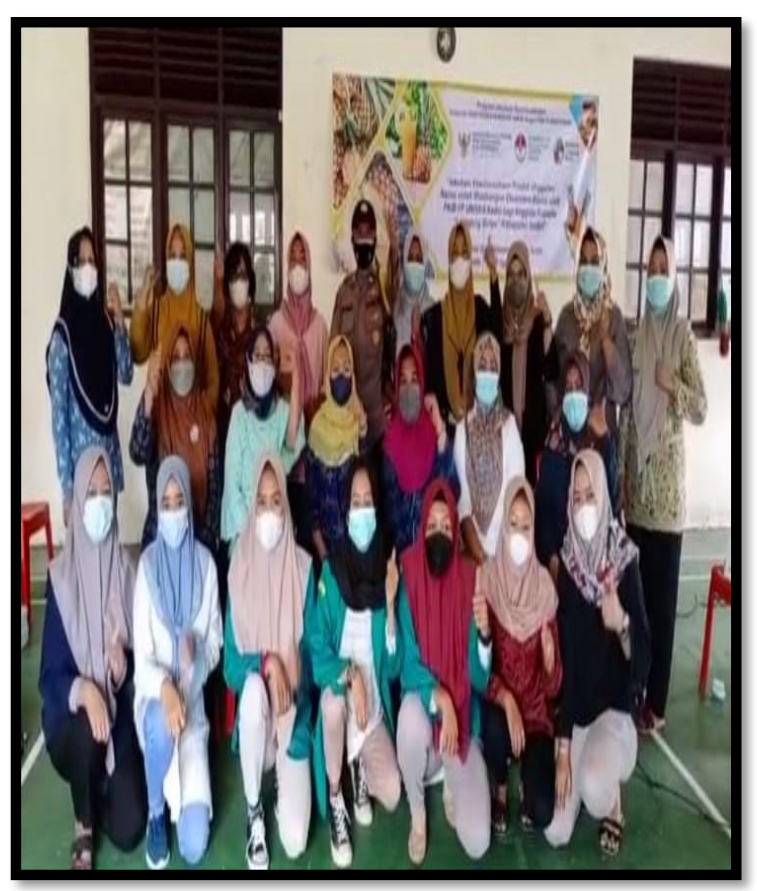

Gambar 5. Tim narasumber dan peserta 


\section{Penutup}

Simpulan

Mentoring dan sosialisasi pelatihan ketrampilan tentang teknologi pengemasan produk olahan nanas dapat menambah ilmu yang bermanfaat bagi kelompok tani PKK Mandiri. Hasil yang dicapai menjadi target jangka pendek yaitu dapat melakukan pengolahan nanas serta cara mengemas olahan yang bermutu. Adapun target jangka panjang adalah memotivasi mendirikan UMKM yang berskala lokal maupun nasional dengan adanya kerjasama kemitraan dengan pihak pemerintah, swasta atau pihak bank yang bisa membantu dana untuk usaha bisnis. Pihak desa sangat mendukung kegiatan pengabdian kepada masyarakat.

\section{Saran}

Pelatihan dan sosialisasi di wilayah desa Badaban dapat dijadikan contoh kegiatan yang dapat mendorong berkembangnya UMKM serta menumbuhkan jejaring market secara nasional. Diharapkan kegiatan ini mendapatkan perhatian yang lebih serius dari pemerintah daerah khususnya kabupaten Kediri agar petani nanas dan ibu-ibu PKK mengerti bagaimana menerapkan teknologi pangan hasil pertanian serta adanya bantuan alat serta sarana prasarana sangat diperlukan karena pada umumnya masyarakat desa memiliki keterbatasan dana untuk membeli alat dan sebagainya.

\section{Ucapan Terimakasih}

Kami dari tim inkubasi bisnis Fakultas Pertanian Universitas Islam Kadiri dan pihak kemitraan kelompok tani nanas dari Desa babadan mengucapkan terimakasih kepada ASDEP Pengembangan Ekosistim Bisnis di Jakarta yang telah membantu dalam pendanaan kegiatan ini. Semoga pelatihan ini menjadi manfaat dan berkembang sejalan dengan kondisi saat ini.

\section{Daftar Pustaka}

Anonim. (2007). Pengemasan Bahan Pangan. Ebookpangan.com.

Astuti, I. Y., Niam, M. A., \& Handayani, T. (2019). Pengembangan Ekonomi Lokal Melalui Olahan Buah Nanas Di Desa Bedali Kecamatan Ngancar Kabupaten Kediri. Cendekia: Jurnal Pengabdian Masyarakat, 1(2), 66. https://doi.org/10.32503/cendekia.v1i 2.596

Elisabeth, D. A. A. (2017). Pengaruh Pengemasan Dan Pelabelan Pada Penerimaan Mi Kering Berbahan Baku Tepung Komposit Ubijalar Dan Keladi. Jurnal Matematika Sains Dan Teknologi, 18(2), 111-119.

Furqon, A. Q. A., Maflahah, I., \& Rahman, A. (2016). Pengaruh jenis pengemas dan lama penyimpanan terhadap mutu produk nugget gembus. AGROINTEK, 10(2), 71-76.

Julianti, E., \& Nurminah, M. (2006). Teknologi Pengemasan. In Departemen Teknologi Pertanian, Fakultas pertanian, Universitas Sumatera Utara.

Kotler, P., \& Keller, K. L. (2009). Manajemen Pemasaran, Edisi 13. Jakarta : Erlangga.

Ksenia, P. (2013). Packaging design as a market tool and desire to purchase. Skripsi. Fakultas Administrasi Bisnis, Lappeenranta, Universitas Ilmu Terapan Saimaa.

Nurcholis, M., Maligan, J. M., \& Widyastuti, E. (2012). Pengemasan Produk Pangan. TPPHP.

Santi, F. U. (2015). Teknik Pengemasan dan Labeling Produk Makanan. Makalah Pengabdian Masyarakat Desa Bejiharjo, Gunungkidul. Yogyakarta: Universitas Negeri Yogyakarta.

Simamora, B. (2007). Panduan Riset Dan Perilaku Konsumen. Jakarta: Gramedia. 
Susetyarsi, T. (2012). Kemasan produk ditinjau dari bahan kemasan, bentuk kemasan dan pelabelan pada kemasan pengaruhnya terhadap keputusan pembelian pada produk minuman mizone di kota semarang. Jurnal STIE Semarang (Edisi Elektronik), 4(3), 1-28. 